\title{
Identifying Physics Teachers Candidate Misconception on Electricity, Magnetism, and Solar System
}

\author{
Ruth Novi Kornalia Mellu ${ }^{1}$, Doni T. Baok ${ }^{2}$ \\ STKIP SoE, Indonesia ${ }^{1,2}$ \\ ruthmellu87@gmail.com¹, donibaok8@gmail.com²
}

Received: March $31^{\text {st }}, 2020$. Revised: June $29^{\text {th }}, 2020$. Accepted: July $1^{\text {st }}, 2020$

\section{Keywords :}

Misconception; Three Tier

Multiple Choice Model of

Diagnostic Test; Electricity;

Magnetism; Solar System

\begin{abstract}
Misconception is a concept contradicts with scientific definitions or definitions approved by experts of particular field. Learners' misconception cannot be eliminated but minimized so they do not grasp incorrect concept which can be identified through diagnostic tests. A research had been conducted to identify physics student teacher misconception. The research was undertaken using qualitative method with survey design. The population covered whole physics major students with 30 students of $6^{\text {th }}$ semester as samples. Data collection was done by giving three tier multiple choice model of diagnostic test developed by Ambarwati on electricity, magnetism, and solar system materials. Data source of this study was primary data source since data was taken directly from research subjects. Data was analyzed using descriptive qualitative data analysis technique. The result showed that $18 \%$ students experienced misconception, $40 \%$ partially understood, $12 \%$ fully understood, and $30 \%$ did not understand concept. $20 \%$ misconception identification of electricity comprised static electric, determining physical quantity on circuit, defining electrical energy and power in daily life; $18 \%$ magnetism material on how to make magnet or determining poles that affected electromagnetic induction; and 17\% solar system material about characteristics of astronomical objects and emerging phenomena due to climate changing on earth surface. the identifications result implied a demand of developing and applying innovative, creative, and appealing learning in remediating and fixing misconception.
\end{abstract}

\section{INTRODUCTION}

Physics is a major in science which concentrates in natural phenomena, symptoms, and facts that its learning process requires comprehension of concepts and critical thinking. Physics learning is a part of introducing nature as learners' learning environment with an expectation that this learning type enhances students' understanding of concept [1]. However, owing to abstract phenomena and plenty formula, 
students generally perceive physics learning unpleasant. This causes students to possess misconception. Misconception refers to a concept that goes against scientific definitions or definitions accepted by experts in the field [2]. Students' misconception cannot be dissipated but corrected so they do not get wrong concept.

Wandersee, et al [2] proposed that misconception occurred in most parts of physics. This was presented in 700 studies regarding misconception, there were 300 studies on mechanics, 159 studies on electricity, and 70 studies on heat, optic, and materials nature misconception. Besides, there were 35 studies about misconception on earth and outer space and also 10 studies on modern physics misconception. These studies depicted high amount of misconception in physics with high opportunity of improvement. Another study related to misconception was undertaken by Artiawanti, et al [3] who presented that students misperceived the concept that an object velocity with constant move had high value, therefore its velocity was also high. Missa, et al [4] portrayed students' misconception in distinguishing emerging energy because of sliding and non-sliding, differentiating friction, and students' difficulties in determining friction. Handhika, et al [5] also proved that students had misconception in representing Newton's First Law.

Several studies also indicated misconception of physical concepts including Sinulingga \& Theo [6] for dynamic electric material. Students had misconception on tension concept, serial electric circuit, and parallel electric circuit. Resbiantoro \& Aldila [7] performed students concept profile who had misconception in force resultant concept on stationary object, object indolence concept, force resultant effect which had similar direction with object movement concept, and force resultant effect that contradicted with object movement direction concept. Besides, Hermita, et al [8] concerned static electric including electrostatic object that could not pull neutral objects, neutral object was an object without electric load, and the size of pull force between two filled objects based on load measure. Toedtanya \& Wuttiprom [9] covered energy concept as well as Safriana \& Nuraini [10] found misconception on mechanics concept about guideline framework centered on self, heavy object fell faster than light object, object mass could make object stop moving, object movement was force representation on objects and force source on object was a result of hits. Other research were Riggs [11] about black hole, Syuhendri [12] about gravitation, Dessytya, et al [13] for gravitation force concepts, light pace, frequency and amplitude, static electric force, and visible objects [13] and Busyairi \& Muhammad [14] who indicated students' misconception on linear, vertical, and parabolic movement concept. Suma, et al [15] discovered students' misconception on electricity material whereas Tumanggor, et al [16] found misconception on wave frequency, sound wave, and medium objects. Misconception analysis results need further analysis and this implied that misconception needed to be fixed so students could have correct comprehension.

Misconceptions in physics can be analyzed using three tier multiple choice model of diagnostic test. It is an evaluation measurement method to identify problems students deal with which consists of multiple choice, rationale selection and level of confidence. The benefit of this test is its ability to diagnose students' misconception deeper, to determine parts of material that need emphasis in learning and to plan better learning in order to reduce students' misconception [17]. A research regarding the use of diagnostic test to identify students' misconception was conducted by Wahyuningsih, et al [18], Agnes, et al [19], Hermita, et al [8], Handayani \& Rukmana [20] and Zukhruf [21] who developed an instrument and utilized diagnostic test instrument to compare, identify, and diagnose misconceptions in physical concept. Beside diagnostic test instrument, misconception could also be analyzed using Certain of Response Index (CRI).

The CRI is frequently used in social sciences [22], particularly in surveys, where a respondent is requested to provide the degree of certainty he has in his own ability to select and utilize well-established knowledge, concepts or laws to arrive at the answer [22]. The CRI is usually based on some scale, for example, the six-point scale (0-5) in which 0 implies no knowledge (total guess) of methods or laws required for answering a particular question while 5 indicates complete confidence in the knowledge of the principles and laws required to arrive at the selected answer [23]. Beside that If the degree of certainty is low (CRI of 0-2) then it suggests that guesswork played a significant part in the 
determination of the answer. Irrespective of whether the answer was correct or wrong, a low CRI value indicates guessing, which, in turn, implies a lack of knowledge. If the CRI high (CRI of 3-5), then the respondent has a high degree of confidence in his choice of the laws and methods used to arrive at the answer. In this situation (CRI of 3-5), if the student arrived at the correct answer, it would indicate that the high degree of certainty was justified [23]. However, if the answer was wrong, the high certainty would indicate a misplaced confidence in student's knowledge of the subject matter. This misplaced certainty in the applicability of certain laws and methods to a specific question is an indicator of the existence of misconceptions [23]. Some studies implementing CRI analysis and instrument were Hasan, et al [23], Utami \& Wulandari [24], and Khoiriyah [25] who proved that identification result with CRI could help teacher to define learners' degree of concept comprehension based on certainty level and determine correct way or method to remediate misconception. Therefore, teachers were expected to be able to develop diagnostic test instrument with CRI analysis whys was applicable to identify students' misconception.

Teacher is a part of learning process that plays crucial role in the enhancement of students' concept comprehension. Therefore, teacher must have good competence and understanding to avoid misleading students as well as develop appropriate instrument in identifying students' misconception. Physics Education Program students are physics teacher candidates who are expected to understand concepts well so they can be well-qualified and competent graduates. Based on observation result toward STKIP SoE physics students learning on Physical Misconception Remediation subject, it was found that $60 \%$ students experienced misconception which generally occurred on physical concepts with abstract nature. Microseption that often appear, is misconseption on the consept physic, that have the abstract ts character. This physic conceps consist of electricity concept, magnetism, and sun that only explained in theoritsm. Chompprehension from the abstract concet nedd the highest thinking and critic so this concept can be explained by students as a teacher candidate and receaved by students. This was caused by students' lack of understanding concept to explain and interpret concept. Hence, this research was undertaken to identify misconception among physics student teacher candidates by administering three tier multiple choice diagnostic test developed by Ambarwati on electricity, magnetism, and solar system material [26]. This instrument emendabled based on junior high school comprehension, and used on candidate teachers so the colage students can evolving the critict thinking abilityby understending concept that abstract character. This research was expected to provide description on misconception students had so further innovation could be taken to learning strategy and materials and physical concepts learning materials substance to remediate the misconception.

\section{METHOD}

This research was a qualitative research with survey research method which was conducted in Sekolah Tinggi Keguruan dan Ilmu Pendidikan (STKIP) SoE. STKIP SOE lies on Soe city, South middle Timor regency, East Nusa Tenggara Province that build in year 2013 and have 5 study program. Subjects of this research were all physics students of STKIP SoE with purposive sampling technique to get the samples in which were 30 students from the $6^{\text {th }}$ semester. Data source of this research was primary data source since data was collected directly from research subjects [27] [28]. The study was done by administering written test using three tier multiple choice model of diagnostic test instrument developed by Ambarwati. The instrument was given to samples to gather information related to students' misconception on electricity, magnetism, and solar system. The test instrument was developed based on junior high school students' level of understanding with 35 test items which consisted of 15 items on electricity, 10 items on magnetism, and 10 test items on solar system materials. This diagnostic test instrument had three levels which were answer choice for first level, reason choice for second level, and confidence choice for third level based on CRI instrument [26].

Three tier multiple choice type of diagnostic test instrument used in this research had been validated and before giving the test to subjects, it had been edited to review the instrument developed by Ambarwati to be revised as needed. The second step was coding to check tryout result of instrument then the 
researcher did misconception analysis using CRI. The third step was tabulating to do groupings in order to determine how many percent's (\%) respondents who had misconception [26] [27] [28].

Data analysis technique of this research was descriptive qualitative analysis technique. It meant that gained data in form of answer, reason, and confidence choice was described in form of table or chart to clarify study result and students' concept understanding. Misconception analysis was done using CRI analysis to portray respondents' confidence degree toward answer choice truth given toward each test item [10] [25]. Respondents' comprehension level based on CRI analysis was categorized into whole comprehension, half comprehension, misconception, and no comprehension as shown in Table 1 [15] [26].

Table 1. Comprehension Level Categorization

\begin{tabular}{cccc}
\hline Answer & Reason & CRI Score & Description \\
\hline Correct & Correct & $>2,5$ & Whole Comprehension \\
Correct & Correct & $<2,5$ & Half Comprehension \\
Incorrect & Correct & $<2,5$ & Half Comprehension \\
Correct & Incorrect & $>2,5$ & Half Comprehension \\
Incorrect & Correct & $>2,5$ & Half Comprehension \\
Incorrect & Incorrect & $>2,5$ & Misconception \\
Incorrect & Incorrect & $<2,5$ & No Comprehension \\
\hline
\end{tabular}

Percentage of each comprehension level based on answer choice, reason choice, and confidence level was analyzed using the following formula [6] [26]:

$$
P=\frac{f}{N} \times 100 \%
$$

Details :

$P \quad$ : percentage of each comprehension level

$f \quad$ : Total students on each comprehension level

$N \quad$ : Amount of all students

\section{RESULTS AND DISCUSSIONS}

Obtained data was in form of answer choice, reason choice, and level of confidence which was analyzed descriptive qualitatively by calculating students' amount percentage then classified students' concept comprehension level based on degree of concept understanding with whole comprehension, half comprehension, misconception, and no comprehension categories [26]. The classification result of students' concept comprehension level for electricity, magnetism, and solar system was presented in Table 2.

Table 2. Percentage Recapitulation of Concept Comprehension Level

\begin{tabular}{llccc}
\hline No & Category & $\begin{array}{c}\text { Electricity } \\
\text { percentage (\%) }\end{array}$ & $\begin{array}{c}\text { Magnetism } \\
\text { percentage (\%) }\end{array}$ & $\begin{array}{c}\text { Solar system } \\
\text { percentage (\%) }\end{array}$ \\
\hline 1 & Misconception & 20 & 18 & 17 \\
2 & Half comprehension & 36 & 43 & 40 \\
3 & No comprehension & 32 & 31 & 28 \\
4 & Whole comprehension & 12 & 9 & 15 \\
\hline
\end{tabular}


Table 2 portrayed that solar system material gained lower misconception compared to other materials. This indicated that students gave incorrect answer and choice of reason but had high confidence level. Furthermore, students showed higher percentage on whole comprehension and half comprehension in solar system material apart from two other materials. This implied that students gave correct answer with correct reason and either high or low confidence level.

Table 2 also indicated that subjects had higher misconception on electricity material compared magnetism and solar system. Some contributing factors were students' inability to differentiate electric charge, lines of force/induction, electric pressure or voltage, difference in electric potential, and electric current inside or outside electrical circuit. It also occurred since students could not explain static electricity phenomenon and determine physical quantity in circuit well and correctly. In addition, students could not determine quantity of electric energy and force in daily life. Their misconception of magnetism reached $18 \%$ and $17 \%$ because of their lower competence in explaining how magnet was produced, determining poles of the produced magnet and explaining factors affecting electromotive force. On the other hand, students could not describe characteristics of astronomical objects and phenomena happened as result of temperature changing on earth surface in solar system.

On half understand category, magnetism reached $43 \%$ compared to the other two. This was because students understood the answer to questions but their selection of rationale remained wrong. They were less deliberate in considering suitable reasons to describe concept of their proposed answers. Subjects had the knowledge so they had the right answer but they did not have whole understanding on electricity, magnetism, and solar system which failed them to link the concepts and get the correct reason.

The percentage of electricity material reached $32 \%$ in do not understand category. This happened because their answer did not fit their selection of reasons and subjects did not understand questions correctly. Concept understanding emerges from students' competence in absorbing concept and relating available concepts but they had less understanding on concepts which resulted in wrong choice of answer or rationale. In fully understand category, the percentage of solar system was $15 \%$ and reached highest place compared to magnetism and electricity. The cause was most students gave correct answers on questions along with correct selection of reasons. Their result confirmed that students acquire the ability to choose correct answer, explain reason, and relate concepts to determine suitable reasons.

Table 3. Misconception Physic Concept

\begin{tabular}{|c|c|}
\hline Misconception & Explanation \\
\hline $\begin{array}{l}\text { To give a spouse between things and } \\
\text { electric capacity concept } \\
\text { To give electroscope position when electric } \\
\text { capacity nearer to the electroscopenetral } \\
\text { To give electric curent to the series of } \\
\text { voltage sourcein a series of lamp } \\
\text { To give a change obstacle and electric } \\
\text { energy in a series and paralel } \\
\text { To give a energy electricity base on electric } \\
\text { tools in our life every day }\end{array}$ & $\begin{array}{l}\text { Electricity concept on the sub material } \\
\text { static electric in explain fenomenaon static } \\
\text { electricity and physical quantities in the } \\
\text { electrical circuit }\end{array}$ \\
\hline $\begin{array}{l}\text { Method to show how to make magnetic } \\
\text { based on picture } \\
\text { To show the direction in galvanometry } \\
\text { To show the direction in voltage at } \\
\text { transformer input }\end{array}$ & $\begin{array}{l}\text { Magnetism on the sub- material how to } \\
\text { make magnetic and poles which resulted } \\
\text { also factor that influenced GGL induction }\end{array}$ \\
\hline $\begin{array}{l}\text { To Show feature of things on the sky } \\
\text { To show effect the line revolve of planets } \\
\text { organized as elips }\end{array}$ & $\begin{array}{l}\text { Solar system on the sub material in the sky } \\
\text { objects }\end{array}$ \\
\hline
\end{tabular}


Misconception-misconception that shown in Table 3, is an misconception that experienced students prospective physics teachers, based on answers analysis, reason selection, and confidence the most numbers of students, on every concept of electricity, magnetism, and the solar system. Based on Table 3 , obstainable that electrical concept university students unable to explain and to show about concept electric charge, strong electric curent, and electrical power in daily life. On magnetism concept and solar system, students also unable to get the way the making and direction of magnet also students still dificult to descript character from the sky objects. This problem show that students used intusion thingking in answaering and showing the motive. Intusion thinking is thinking that usually get from observe, of the object or continous events, finally, spantaneously if to face up any physic problem that appear in spontaneous mind [2] [29].

The average of students' comprehension is presented in Figure 1.

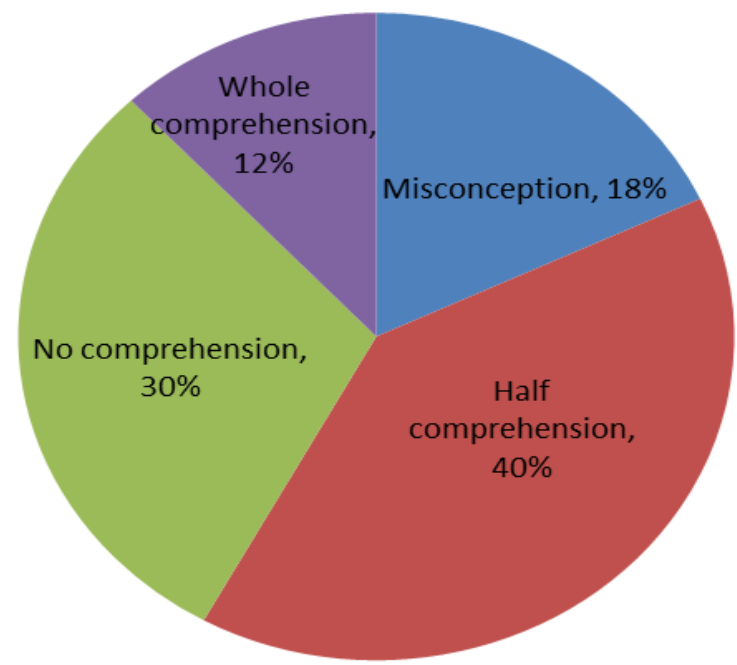

Fig 1. Students' Comprehension Average

Based on Figure 1, it was revealed that $40 \%$ of Physics Education Program students only had half comprehension of whole electricity, magnetism, and solar system material concepts being evaluated. This was due to high amount of students who had incomplete initial preconception which could be derived from uncertain circumstance according to experts. Students also had associative thinking but unable to relate events or phenomena in test items with concepts they found. This half comprehension level could also lead to misconception since they had low competence to link abstract concepts and provide logical and systematic explanation. Therefore good understanding of concept was basically required to help learners in increasing their background knowledge. This could occur by applying methods, models, and media enabling conceptual understanding. In their study, Permatasari, et al [30] proposed that the use of contextual-based Predict-Observe-Explain learning model could improve activities and conceptual understanding. Boimau \& Mellu [31] [32] also applied learning media in form of teaching aids to improve conceptual understanding as well as Roistiya, et al [33] who developed MW4T (Mechanics Wave Four Tier) as a medium to measure concept comprehension.

Comprehension level of whole comprehension and no comprehension showed average percentage of $12 \%$ and $30 \%$ which implied that only few students had good comprehension level so they could relate each concepts appropriately and correctly whereas students with no understanding could not relate concepts correctly. This was depicted in their answer, reason, and confidence selection which could not relate between their choice and explanation. Besides, $18 \%$ of average students had misconception on those concepts. This phenomenon occurred in analyzing static electric phenomena, defining physical quantity in circuit, determining the quantity of electric energy and power in daily life, explaining how magnet was produced, or defining produced poles and factors affecting electromagnetic induction as well as explaining astronomical objects and phenomena occurred due to climate changing on earth surface. This indicated that their ability to link concepts remained low due to half concept understanding. 
Therefore, logical reasoning and critical thinking were fundamentally needed to improve their conceptual understanding competence.

Several studies that supported this research included Lemmer \& Morabe [34] who proved that misconception on basic magnetism material could be remediated using analogic reasoning. This kind of reasoning enabled students to relate abstract events or phenomena with physical concepts they found from their surroundings. This could also help improve their critical thinking skill in understanding concepts. Safrina, et al [35] in their research also implied that students' ability in understanding dynamic electric concept must be enhanced by cultivating understanding and arguing skill using innovative and creative learning method to boost their learning motivation. Besides, Bani \& Salameh [36] argued that identifying students' misconception could be done using answer method and FCI so their misconception could be mended. Kania, et al [37] revealed the effectiveness of contextual learning to increase students' critical thinking and concept mastery. Meanwhile Nasihah, et al [38] also implied peer tutor effect in Problem Based Learning toward the improvement of critical thinking skill.

The result of this stud gave a description on the needs of creative and innovative strategy, method, media, and learning material substance to overcome students' misconception. Samsudin, et al [39] who implemented computer simulation based on PDEODE (Predict, Discuss, Explain, Observe, Discuss, and Explain) learning strategy in analyzing misconception found that the frequency of students with misconception was decreased into 0.21 in low category. Admoko, et al [40] applied Guided Discovery learning model with virtual laboratory simulation in learning process which was efffective to remediate students' misconception. Sianturi, et al [41] did Multiple Representation Preference exploration in learning to increase students' scientific concept awareness which could be useful in identifying misconception. Besides, Hesti, et al [42] proposed that the use of analogy test-based in learning could help to mend students' misconception and Oktavianty, et al [43] demonstrated that the effect of remediating misconception in physical learning cound reduce misconception. Thus, correct conceptual understanding of physics student teacher candidates should be developed by implementing innovative learning method to lessen and mend misconception.

\section{CONCLUSION AND SUGGESTION}

Based on analysis result, there were $18 \%$ students who had misconception, $40 \%$ half understood, $12 \%$ fully understood, and $30 \%$ students had no comprehension on concepts. Misconception identification results were $20 \%$ on electricity topic covered static electric phenomena, defining physical quantity in circuit and energy as well as electric power in daily life; $18 \%$ on magnetism material which consisted of how magnet was produced or determining produced poles and factors affecting electromagnetic induction; and $17 \%$ on solar system topic concerning astronomical objects characteristics and emerging phenomena due to climate changing on earth surface. These results indicated the needs of innovative, creative and appealing learning development and implementation as well as in remediating and repairing misconceptions. This study could be continued by remediating student's misconception using appropriate method, model, media, and strategy to improve students' conceptual understanding.

\section{REFERENCES}

[1] Sholikah, A., Febriyanti, D. S., \& Kurniawan, B. R. (2020). Analisis Miskonsepsi Mahasiswa Calon Guru Fisika Menggunakan Quizziz Pada Pokok Bahasan Optika Geometri. Jurnal Penelitian Pembelajaran Fisika, 11(1): 27-36.

[2] Suparno, P. (2013). Miskonsepsi \& perubahan konsep dalam pendidikan fisika. Gramedia Widiasarana.

[3] Artiawati, P. R., Mulyani, R., \& Kurniawan, Y. (2016). Identifikasi Kuantitas Siswa Yang Miskonsepsi Menggunakan Three Tier-Test Pada Materi Gerak Lurus Beraturan (GLB). JIPF (Jurnal Ilmu Pendidikan Fisika), 1(1): 13-15. 
[4] Missa, L., \& Melu, R. N. K. (2017). Pengembangan Instrumen Tes Diagnostik Multiple choice untuk mengidentifikasi Miskonsepsi Siswa Pada Materi Gaya. STKIP SoE.

[5] Handhika, J., Cari, C., \& Suparmi, A. (2017, January). Students' representation about Newton law: consequences of "zero intuition". In Journal of Physics: Conference Series (Vol. 795, No. 1, p. 012057). IOP Publishing.

[6] Sinulingga, P. E. N. D. I., \& Hartanto, T. J. (2015). Analisis Potensi Miskonsepsi Mahasiswa Prodi Pendidikan Fisika Universiotas Palangkaraya Pada Topik Listrik Dinamis. In Prosiding seminar nasional fisika dan aplikasinya I. Universitas padjajaran (pp. 34-42).

[7] Resbiantoro, G., \& Nugraha, A. W. (2017). Miskonsepsi mahasiswa pada konsep dasar gaya dan gerak untuk sekolah dasar. Jurnal Pendidikan Sains (JPS), 5(2): 80-87.

[8] Hermita, N., Suhandi, A., Syaodih, E., Samsudin, A., Johan, H., Rosa, F., ... \& Safitri, D. (2017). Constructing and implementing a four tier test about static electricity to diagnose pre-service elementary school teacher'misconceptions. JPhCS, 895(1): 012167.

[9] Toedtanya, K., \& Wuttiprom, S. (2017). The investigation of high school student's energy concept by using analogies. JPhCS, 901(1): 012119.

[10] Safriana, S., \& Fatmi, N. (2018). Analisis Miskonsepsi Materi Mekanika pada Mahasiswa Calon Guru Melalui Force Concept Inventory dan Certainty of Response Index. Jurnal Pendidikan Sains Indonesia (Indonesian Journal of Science Education), 6(2): 90-94.

[11] Riggs, P. J. (2019). Black holes: basic concepts and popular misconceptions. Physics Education, 54(6): 065015.

[12] Syuhendri, S. (2019, April). Student teachers' misconceptions about gravity. In Journal of Physics: Conference Series (Vol. 1185, No. 1, p. 012047). IOP Publishing.

[13] Desstya, A., Prasetyo, Z. K., \& Suyanta, S. (2019, October). Understanding of elementary school teachers on physical concepts. In Journal of Physics: Conference Series (Vol. 1318, No. 1, p. 012077). IOP Publishing.

[14] Busyairi, A., \& Zuhdi, M. (2020). Profil Miskonsepsi Mahasiswa Calon Guru Fisika Ditinjau Dari Berbagai Representasi Pada Materi Gerak Lurus Dan Gerak Parabola. Jurnal Pendidikan Fisika dan Teknologi, 6(1): 90-98.

[15] Suma, K., Sadia, I. W., \& Pujani, N. M. (2018). The identification of the 11th grade students' prior knowledge of electricity concepts. In IOP Conf. Series: Journal of Physics: Conf. Series (Vol. 1040, p. 012038).

[16] Tumanggor, A. M. R., Kuswanto, H., \& Ringo, E. S. (2020, January). Using four-tier diagnostic test instruments to detect physics teacher candidates' misconceptions: Case of mechanical wave concepts. In Journal of physics: conference series (Vol. 1440, No. 1, p. 012059). IOP Publishing.

[17] Mubarak, S., Susilaningsih, E., \& Cahyono, E. (2016). Pengembangan tes diagnostik three tier multiple choice untuk mengidentifikasi miskonsepsi peserta didik kelas xi. Journal of Innovative Science Education, 5(2): 101-110.

[18] Wahyuningsih, T., Raharjo, T., \& Masithoh, D. F. (2013). Pembuatan Instrumen Tes Diagnostik Fisika SMA Kelas XI. Jurnal Pendidikan Fisika, 1(1): 111-117.

[19] Agnes, D., Kaniawati, I., \& Danawan, A. (2015). Analisis Deskriptif Tes Tiga Tingkat Materi Optika Geometri dan Alat Optik. Prosiding Simposium Nasional Inovasi dan Pembelajaran Sains, 2015: 597-600.

[20] Handayani, S. L. (2018). Perbandingan Miskonsepsi Mahasiswa PGSD UHAMKA Materi Optik Geometri. Jurnal Ilmiah Pendidikan Dasar, 5(1): 44-56.

[21] Zukhruf, K. (2018). Mengidentifikasi Miskonsepsi Fluida Statis pada Mahasiswa Calon Guru Fisika Universitas samudra. Jurnal Pendidikan Fisika dan Sains, 1(02): 11-16.

[22] Webb, J. (1994). Webb.pdf.

[23] Hasan, S., Bagayoko, D., \& Kelley, E. L. (1999). Misconceptions and the certainty of response index (CRI). Physics education, 34(5): 294-299.

[24] Utami, D. N., \& Wulandari, H. R. T. (2016, November). The use of astronomy questions as an instrument to detect student's misconceptions regarding physics concepts at high school level by using CRI (Certainty of Response Index) as identification methods. In Journal of Physics: Conference Series (Vol. 771, No. 1). 
[25] Khoiriyah, A. (2018). Identifikasi Miskonsepsi Siswa Dengan Menggunakan Metode Certainty Of Response Index (CRI) Materi Gaya Dan Gerak Kelas IV Nurul Huda Di Ponegoro. Universitas Islam Walisongo Semarang.

[26] Ambarwati, D. R. (2011). Miskonsepsi pada materi kelistrikan, kemagnetan dan tata surya siswa SMP (Doctoral dissertation, Universitas Negeri Semarang).

[27] Sugiyono. (2018). Metode Penelitian Kualitatif. Bandung: Alfabeta.

[28] Sugiyono. (2013). Metode Penelitian Pendidikan. Bandung: Alfabeta.

[29] Nurulwati, N., Veloo, A., \& Ali, R. M. (2014). Suatu tinjauan tentang jenis-jenis dan penyebab miskonsepsi fisika. Jurnal Pendidikan Sains Indonesia (Indonesian Journal of Science Education), 2(1): 87-95.

[30] Permatasari, O. I., \& Marwoto, P. (2018). Penerapan Model Pembelajaran Predict-ObserveExplain Berbasis Kontekstual untuk Meningkatkan Aktivitas dan Pemahaman Konsep Siswa SMP. JIPF (Jurnal Ilmu Pendidikan Fisika), 2(2): 50-53.

[31] Boimau, I., \& Mellu, R. N. K. (2017). Prototype of Physics Lessons Based on Microcontroller to Increases Students' Conceptual Understanding. International Journal of Science and Research (IJSR), 6(11): 1812-1818.

[32] Boimau, I., \& Mellu, R. N. K. (2019). Development of Microcontroller-Based Free Fall Motion Learning Materials to Increase Students' Conceptual Understanding. JIPF (Jurnal Ilmu Pendidikan Fisika), 4(1): 45-55.

[33] Roistiya, H., Putra, I. A., \& Pertiwi, N. A. S. (2019). Pengembangan Instrumen MW4T (Mechanic Wave Four Tier) Diagnostic Test Untuk Mengukur Pemahaman Konsep Gelombang Mekanik. DIFFRACTION, 1(2): 14-21.

[34] Lemmer, M., \& Morabe, O. N. (2017). Concept confusion and concept discernment in basic magnetism using analogical reasoning. Physics Education, 52(4): 045002.

[35] Safrina, I., Maknun, J., \& Hasanah, L. (2017). Analysis of Student's Skills on the Concept Dynamic Electricity. JPhCS, 895(1): 012104.

[36] Bani-Salameh, H. N. (2016). Using the method of dominant incorrect answers with the FCI test to diagnose misconceptions held by first year college students. Physics Education, 52(1): 015006.

[37] Kania, D., Rubini, B., \& Ardianto, D. (2020). Pengembangan Pembelajaran Pada Materi Tekanan Zat Untuk Keterampilan Berpikir Kritis Dan Penguasaan Konsep Siswa SMP. Journal of Science Education And Practice, 2(1): 58-69.

[38] Nasihah, E. D., Supeno, S., \& Lesmono, A. D. (2020). Pengaruh Tutor Sebaya Dalam Pembelajaran Problem Based Learning Terhadap Keterampilan Berpikir Kritis Fisika Siswa SMA. Jurnal Pendidikan Fisika, 8(1): 44-57.

[39] Samsudin, A., Kaniawati, I., Suhandi, A., Fratiwi, N. J., Wibowo, F. C., Malik, A., \& Costu, B. (2019, November). Unveiling students' misconceptions through computer simulation-based PDEODE learning strategy on dynamic electricity. In Journal of Physics: Conference Series (Vol. 1280, No. 5, p. 052050). IOP Publishing.

[40] Admoko, S., Yantidewi, M., \& Oktafia, R. (2019, December). The Implementation of Guided Discovery Learning Using Virtual Lab Simulation To Reduce Students' Misconception on Mechanical Wave. In Journal of Physics: Conference Series (Vol. 1417, No. 1, p. 012089). IOP Publishing.

[41] Sianturi, I. N. (2019, June). Exploring Multiple Representation Preference to Develop Students Misconception Inventory in Measuring of Students Science Conception Awareness. In Journal of Physics: Conference Series (Vol. 1233, No. 1, p. 012039). IOP Publishing.

[42] Hesti, R., Maknun, J., \& Feranie, S. (2017). Text Based Analogy in Overcoming Student Misconception on Simple Electricity Circuit Material. JPhCS, 895(1): 012146.

[43] Oktavianty, E., Haratua, T. M. S., \& Anuru, M. (2018). The effect of remediation on reducing misconception: a metaanalysis of student thesis on physics education. JPhCS, 1013(1): 012039. 